\title{
Comparison of Animal Productivity and Profitability Between a Silvopastoral System (Brachiaria brizantha Associated with Leucaena leucocephala) and a Conventional System (B. brizantha+Chicken Manure)
}

\author{
${ }^{1} \mathrm{~J}$. A. Jimenez-Trujillo, ${ }^{2} \mathrm{M}$. Ibrahim, ${ }^{2} \mathrm{D}$. Pezo, ${ }^{3} \mathrm{~F}$. Guevara-Hernandez, \\ ${ }^{3} \mathrm{H}$. Gomez-Castro, ${ }^{4} \mathrm{~J}$. Nahed-Toral and ${ }^{3} \mathrm{R}$. Pinto-Ruiz \\ ${ }^{1}$ Centro Academico Regional de la Universidad Autonoma Agraria Antonio Narro, \\ Cintalapa, Chiapas, Mexico \\ ${ }^{2}$ Centro Agronomico Tropical de Investigacion y Ensenanza, Turrialba, Costa Rica \\ ${ }^{3}$ Facultad de Ciencias Agronomicas, Universidad Autonoma de Chiapas, Villaflores, Chiapas, Mexico \\ ${ }^{4}$ El Colegio de la Frontera Sur, San Cristobal de las Casas, Chiapas, Mexico
}

\begin{abstract}
The impacts of a Silvopastoral System (SPS) upon animal productivity (daily and total weight gain), biomass availability and production system profitability were evaluated in two contrasting production systems, one with Brachiaria brizantha pasture and chicken manure feed and the other with Brachiaria brizantha in association with Leucaena leucocephala. The study was carried out in San Juan Chiquito de Esparza, in the county of Puntarenas, Costa Rica with an average temperature of $27^{\circ} \mathrm{C}$ and with an annual precipitation that varied between the 1500 and $2000 \mathrm{~mm}$. The study was carried out in the dry as well as the rainy season, to be able to include data from both periods. To evaluate animal productivity, 12 weaned calves of mixed breed Brown-Brahmin with homogeneous phenotypic characteristics and an average weight of $193.83 \pm 20.71 \mathrm{~kg}$ were randomly distributed in an experimental design with two treatments and six repetitions. Biomass availability and grass and leucaena quality were measured in two treatments and during the wet and dry season. Economic analysis was performed with a partial budget and a 12 years model of both systems. The ANOVA results did not show significant differences with respect to daily or total weight gain between treatments in either wet or dry seasons but calves experienced significantly more weight gain in the rainy season than in the dry season, regardless of treatment. With regard to the Leucaena quality variables, significant differences were found between seasons for dry mass and tannins not for raw protein, DMD in vitro and mimosine. For the Brachiaria pasture, significant differences were found respect to availability dry mass, raw protein and DMD in vitro between treatments and between seasons. Economic results indicated that the silvopastoral system was more profitable than the conventional system in the 12 years model used. These overall results represent an important component of a technological innovation for the tropical livestock.
\end{abstract}

Key words: Forage trees, biomass availability, biomass quality, Internal Return Rate, NCV, partial budget

\section{INTRODUCTION}

One of the principle problems facing livestock production and especially dual purpose cattle raising is the production of feed of sufficient quantity and quality. In summer months, the scarcity and low quality of pasture grasses has historically led to animal loss (mortality), a deficit in milk production and an accompanying reduction of income for producers (Holguin and Ibrahim, 2005). This reality has brought about a steady and constant increase in the area devoted to cattle raising activities, causing the deforestation of vast expanses of forests in order to establish new grazing lands to counteract the low productivity of livestock systems (Camero, 1996; Abarca, 1997). It has been shown that the use of silvopastoral systems is a promising alterative for reducing the use of external inputs in farms, improving forage grass quality and creating less stressful environments for animals all of which can be expressed in the improvements in daily net income and meat production (Lamela et al., 2005).

The present study had as objectives to evaluate and compare the impact of Silvopastoral systems (B. brizantha in association with L. leucocephala) and

Corresponding Author: J.A. Jimenez-Trujillo, Centro Academico Regional de la Universidad Autonoma Agraria Antonio Narro, Cintalapa, Chiapas, Mexico 
conventional systems (B. brizantha pasture in monoculture and chicken manure feed) upon biomass availability and quality changes in live weight of cows and production system profitability

\section{MATERIALS AND METHODS}

Research was carried out on the farm of Don Nelson Benavides, located in the community of San Juan Chiquito de Esparza, Canton de Puntarenas County, Costa Rica. The farm is found within the area influenced by the CATIE-GEF World Bank project, Silvopastoral Approaches for Integrated Ecosystem Management. It has a surface area of 32.13 ha in which 1.76 ha were planted with an association of B. brizantha with L. leucocephala. For the study, 12 weaned calves of mixed Brown-Brahmin breed were distributed in a completely random experimental design with two treatments (Silvopastoral system and Conventional system) and six repetitions. All animals were treated against parasites externally and internally before beginning the trial and 3 months after along with vitamin treatments. All animals had unlimited access to mineralized salt and water to satisfy basic needs. The area of the Silvopastoral system was $1.76 \mathrm{ha}$, divided into eight parcels of $2,200 \mathrm{~m}^{2}$ which were grazed in 6 day periods during the dry season and 8 day periods in the rainy season. The Conventional system had an area of 1.8 ha, divided into two 0.90 ha parcels and grazed for 21 day periods. Within each parcel, cows had access to troughs of chicken manure as well as water and mineral salts.

To discover animal productivity, the calves were kept in a 15 days adaptation period before beginning the experiment. Once started, monthly check-ups were used to study weight gain, across time and in total. Weighing was done in the early morning hours and with $4 \mathrm{~h}$ of fasting in the corral. To find the daily gain, the total difference between initial and final weight of each period was divided by the number of days between weighing. Weight gain by season was the difference between the initial and final weight of each season and total weight gain was the difference between the initial weight at the time the experiment began and the final weight at the end of the experimental stage (Table 1). In the case of the $B$. brizantha and Leucaena association, the variables studied were dry mass, raw protein, the dry matter degradability in vitro (DMD in vitro) and tannins as well as mimosine in Leucaena. Biomass availability was studied in B. brizantha monoculture and in B. brizantha and Leucaena associations. To measure the availability of associated B. brizantha, the Destructive method recommended by Gutierrez (1996) was utilized. With the
Table 1: Daily weight gain by season and in total for calves

\begin{tabular}{|c|c|c|c|}
\hline Indicators & $\begin{array}{l}\text { Brizantha+ } \\
\text { Leucaena }\end{array}$ & $\begin{array}{l}\text { Brachiaria+ } \\
\text { chicken manure }\end{array}$ & $\mathrm{p}$-values \\
\hline \multicolumn{4}{|l|}{ Dry season } \\
\hline No. of calves & 6 & 6 & NA \\
\hline Weight initial ( $\mathrm{kg}$ calves $^{-1}$ ) & $194.26 \pm 13.03$ & $188.34 \pm 23.15$ & NA \\
\hline Weight final (kg calves $\left.{ }^{-1}\right)$ & $236.42 \pm 17.96$ & $224.15 \pm 22.42$ & NA \\
\hline Gain for time (kg calves $\left.{ }^{-1}\right)$ & $42.17^{\mathrm{a}^{*}}$ & $35.81^{\mathrm{a}}$ & 0.2798 \\
\hline Daily gain (kg/calves/daily) & $0.49^{\mathrm{a}}$ & $0.40^{\mathrm{a}}$ & 0.1947 \\
\hline \multicolumn{4}{|l|}{ Rainy season (65 days) } \\
\hline Weight initial (kg calves ${ }^{-1}$ ) & $236.42 \pm 17.96$ & $224.15 \pm 22.42$ & NA \\
\hline Weight final (kg calves $\left.{ }^{-1}\right)$ & $282.87 \pm 16.89$ & $276.83 \pm 27.55$ & $\mathrm{NA}^{* * *}$ \\
\hline Gain for time (kg calves ${ }^{-1}$ ) & $46.45^{\mathrm{a}^{*}}$ & $52.69^{\mathrm{a}}$ & 0.2254 \\
\hline Daily gain (kg/calves/daily) & $0.68^{a}$ & $0.81^{\mathrm{a}}$ & 0.1146 \\
\hline \multicolumn{4}{|l|}{ Total period (154 days) } \\
\hline Total gain (kg calves ${ }^{-1}$ ) & $88.61^{a^{*}}$ & $88.50^{\mathrm{a}}$ & 0.9904 \\
\hline Daily gain (kg/calves/daily) & $0.58^{\mathrm{a}}$ & $0.57^{a}$ & 0.9906 \\
\hline
\end{tabular}

${ }^{*}$ Do averages with different letter in the same line differ statistically according to test of Fisher $(\alpha=0.05) ;{ }^{* *}$ It does not apply

use of a square of $0.25 \mathrm{~m}^{2}, 15$ samples were taken and then the area occupied by Leucaena was determined and subtracted from the total land area, to give the area occupied by the pasture grass. For $B$. brizantha in monoculture, the destructive methodology was also used but with 60 samples. For Leucaena biomass availability, three $1 \mathrm{~m}$ long sections that were randomly distributed over the Leucaena rows. Once the sections were located, the trees were cut to a height of $1 \mathrm{~m}$, level with the soil. Edible plant matter was separated and weighed while still fresh. With these samples, the average weight of $1 \mathrm{~m}$ was established and then multiplied by the lineal meters of Leucaena planted in row.

Collected information was analyzed using an Analysis of Variance (ANOVA) for a Bifactorial structured model, given the combination of a 2-level treatment factor (Silvopastoral and Conventional systems) and a two-level seasonal factor. Financial analysis was conducted with a cost-benefit analysis to evaluate profitability of investing in silvopastoral systems from the producer's perspective. A model was produced that compared the net income of the $B$. brizantha and Leucaena association system with the monoculture $B$. brizantha with supplementary chicken manure feed.

\section{RESULTS AND DISCUSSION}

Weight gain during the study period was significantly different between seasons, regardless of the treatment with the rainy season more productive than the dry season $\left(49.5 \mathrm{~kg}\right.$ calf $^{-1}$ total for both treatments in the wet season versus $38.99 \mathrm{~kg} \mathrm{calf}^{-1}$ in the dry season). It was also found that the daily weight gain was greater in the rainy season, independently of the treatment (Table 2 and Fig. 1 and 2). These results are in agreement with Castillo et al. (2002) and Lopez et al. (2010) which indicate that during the rainy season there is better forage 
Table 2: Leucaena availability and quality

\begin{tabular}{lccc}
\hline Indicators & Dry & Rainy & p-values \\
\hline Availability $\left(\mathrm{kg} \mathrm{ha}^{-1}\right)$ & $267.22^{2^{\mathrm{a}}}$ & $194.33^{\mathrm{a}}$ & 0.6942 \\
Dry matter (\%) & $42.57^{\mathrm{a}}$ & $30.26^{\mathrm{b}}$ & 0.0049 \\
Crude protein (\%) & $24.66^{\mathrm{a}}$ & $25.31^{\mathrm{a}}$ & 0.1838 \\
DMD in vitro (\%) & $57.88^{\mathrm{a}}$ & $60.43^{\mathrm{a}}$ & 0.1002 \\
Tannins & $1.53^{\mathrm{a}}$ & $2.26^{\mathrm{b}}$ & 0.0001 \\
Mimosine & $5.33^{\mathrm{a}}$ & $5.50^{\mathrm{a}}$ & 0.5037 \\
\hline
\end{tabular}

*Do averages with different letter in the same line, differ statistically according to test of Fisher $(\alpha=0.05)$
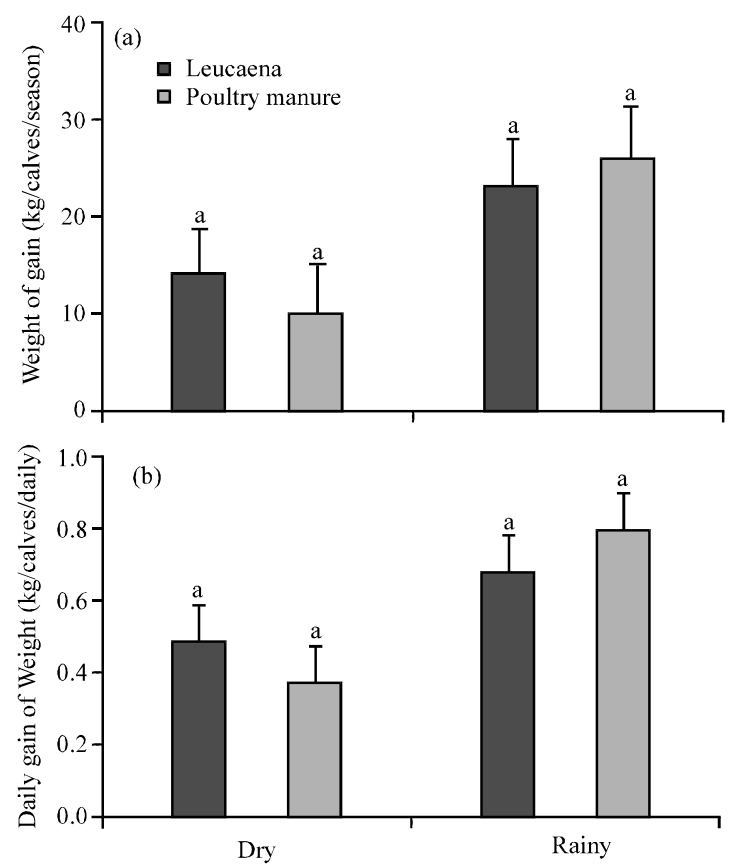

Fig. 1: Weight gain by season (kg/calf/season) and by day $(\mathrm{kg} /$ calf/day $)$

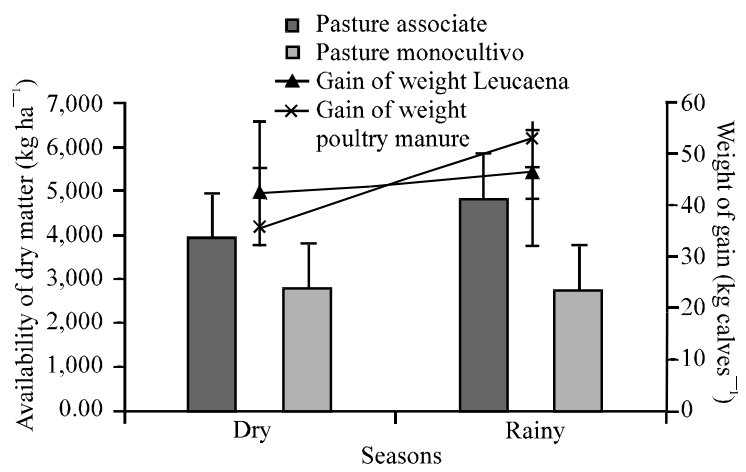

Fig. 2: Availability of pasture and weight gain by season (kg/calf/season)

availability and therefore greater animal productivity, although Obispo et al. (2001) point out that there may be a high availability of pastures, they may not be of high quality and therefore they would not have much effect on animal productivity. In relation to the differences of seasonal and daily weight gain between treatments, no significant differences were found between calves in the Silvopastoral and Conventional system. This would indicate that the use of Leucaena in association with Brachiaria sp. is a viable alternative system, capable of substituting for chicken manure in cattle fattening as found by Simon et al. (2009) who reported that daily weight gain was greater for calves that grazed in pastures with associations of natural grasses with Leucaena (in treatments of 30 and $100 \%$ of total area) than for those that grazed in monoculture pasture $(0.60$ and 0.53 compared to $0.42 \mathrm{~kg} / \mathrm{calf} /$ day, respectively, Fig. 1). Despite the dietary supplement of chicken manure, it was found that the calves in the Conventional system had the same weight gain as those that grazed in the Silvopastoral system. This confirms the research of Castillo et al. (2002) which found that calves that grazed upon stargrass (Cynodon nlemfuensis) in $100 \%$ association with Leucaena had an equal weight gain as those that in addition to grazing in such associations, received a protein-energy supplement (0.78 compared to 0.79 $\mathrm{kg} /$ calf/day, respectively). These results suggest that the integration of Leucaena in pastures is an alternative that makes redundant the use of external inputs for diet supplementation.

As can be observed, the versatility of Leucaena has permitted that it be used as a base for bovine alim entation or as a protein-rich supplement to improve animal productivity, that Leucaena can be a viable option for the substitution of certain concentrates to supplement beef cattle.

It is possible that the calves in the Leucaena system could have shown a greater weight gain than those fed with chicken manure if and when the pasturing periods between rotations were greater and thus preventing the Leucaena foliage from being fresh and thus high in mimosine as mentioned by Garcia et al. (2008b) which reports that the mimosin content is in the superior stratum (material but tender) that which can cause toxic effects affecting the animal in the lost of appetite and gain of weight.

With respect to the availability of Leucaena biomass, it was discovered that there were no significant differences between the dry and wet seasons (267.22 and $194.33 \mathrm{~kg} \mathrm{ha}^{-1}$, respectively), contradicting that indicated by Hernandez et al. (2000) and Sanchez et al. (2005), these final researchers indicate that the wet season is more productive than the dry $(758.80 \pm 209.56 \mathrm{~kg}$ compared to $615.52 \pm 228.84 \mathrm{~kg} \mathrm{ha}^{-1}$, respectively) concluding that precipitation, evaporation rates, plant age and time between grazing are very important factors of foliage 
availability (Table 2). In the case of dry mass content, significant differences were found between seasons with greater content in the dry season than during the rainy period as have reported, Caceres and Gonzalez (1998) and Palma et al. (1999). These researchers indicate that the greater presence of dry mass is found during the dry season, since in this period the scarcity of rainfall leads to less water content in the pastures (Table 2). In reference to the raw protein content and DMD in vitro, there were no significant differences between the wet and dry seasons indicating that these variables were not affected by climatic factors (24.66 and 25.31\% raw protein, respectively). Similar data were reported for Sanchez (2007), Lobo Di Palma (2006) and Galindo et al. (2005). Despite the fact that significant differences did not exist between seasons, it was found that raw protein content and $\mathrm{DMD}$ in vitro was greater during the rainy season. Torres et al. (2005) found a raw protein content of $22.5 \%$ in both seasons although, Delgado and Cairo (2008) indicate that water stress reduces plant quality with respect to raw protein content (Table 2).

For the content of Tannins and Mimosin in the different times of the year, it was found that for the Tannin if significant differences existed, presenting a bigger content for the rain time that for the dry one. The presence of Mimosin did not present significant differences among the times $(\mathrm{p}=0.5037)$, although it is important to mention that a difference of $0.17 \%$ existed (percentage units) among the rain time and he/she dries off (Fig. 2), similar results in the mimosin content (5.34), it was reported by Garcia et al. (2008a) although, this same researcher reports a mimosin content but I lower that in having reported in this investigation (Garcia et al., $2008 b, c)$.

Regarding the availability of Brachiaria pasture in monoculture and in association there existed a greater availability in the associated system than in the monoculture as well as greater contents of dry mass, raw protein and $\mathrm{DMD}$ in vitro as has been reported by several researchers. Andrade et al. (2000), Lopez et al. (2010) and Simon et al. (2009) found that the availability of pastures (B. brizantha, B. decumbens and Panicum maximum, L. leucocephala) was unaffected by associations with tree species (Acacia mangium and Eucalyptus deglupta, Table 3 and Fig. 3).

In relation to dry mass, raw protein content and DMD in vitro, significant differences were found between wet and dry seasons. A greater dry mass content was found in the dry season than in the rainy season while a greater content of raw protein and DMD in vitro was found in the wet season. Similar results have been found by Cuadrado et al. (2004) and Simon et al. (2009) who
Table 3: Availability of dry mass raw protein content and DIVMS in different seasons and treatments

\begin{tabular}{lrrr}
\hline Indicators & $\begin{array}{r}\text { Brachiaria }+ \\
\text { Leucaena }\end{array}$ & $\begin{array}{c}\text { Brachiaria+ } \\
\text { chicken manure }\end{array}$ & p-values \\
\hline Dry & & & \\
Availability of dry matter $\left(\mathrm{kg} \mathrm{ha}^{-1}\right)$ & $3,669.22^{2^{*}}$ & $2,728.28^{\mathrm{a}}$ & 0.1676 \\
Crude protein & $11.63^{\mathrm{a}}$ & $9.73^{\mathrm{b}}$ & 0.0009 \\
Dry matter & $39.76^{\mathrm{a}}$ & $34.36^{\mathrm{a}}$ & 0.5102 \\
DMD in vitro & $54.38^{\mathrm{a}}$ & $55.60^{\mathrm{a}}$ & 0.2171 \\
Rainy & & & \\
Availability of dry matter $\left(\mathrm{kg} \mathrm{ha}^{-1}\right)$ & $4,164.27^{\mathrm{a}}$ & $2,769.65^{\mathrm{a}}$ & 0.0682 \\
Raw protein & $13.17^{\mathrm{a}}$ & $10.23^{\mathrm{b}}$ & 0.0001 \\
Dry matter & $26.58^{\mathrm{a}}$ & $22.23^{\mathrm{b}}$ & 0.0077 \\
DMD in vitro & $55.92^{\mathrm{a}}$ & $53.82^{\mathrm{a}}$ & 0.2576 \\
\hline
\end{tabular}

${ }^{*}$ Do averages with different letter in the same line. differ statistically according to test of Fisher $(\alpha=0.05)$

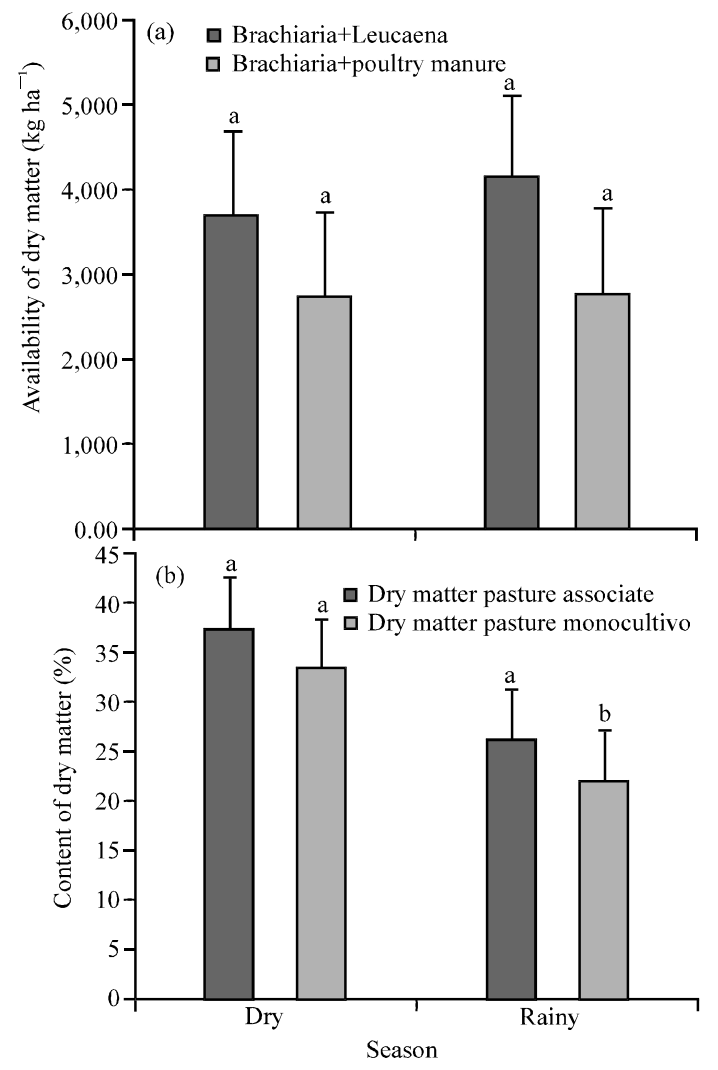

Fig. 3: Availability and content of dry mass in Brachiaria pasture in monoculture and in association

reported a greater content and availability of raw protein in the rainy season (Table 3 and Fig. 4). The establishment costs of a Leucaena forage bank in a pasture was US\$ 1183.7 of which $19.56 \%$ corresponds to labor costs and $80.44 \%$ to inputs. In the case of establishing Brachiaria in monoculture the cost was US\$ 1025.80 of which $13.55 \%$ was attributed to labor and $86.45 \%$ to inputs. The annual management costs of the Silvopastoral system were determined to be US\$ 181.46 of which $72.34 \%$ were labor costs and $27.66 \%$ inputs. On the other hand, 
Res. J. Biol. Sci., 6 (2): 75-81, 2011

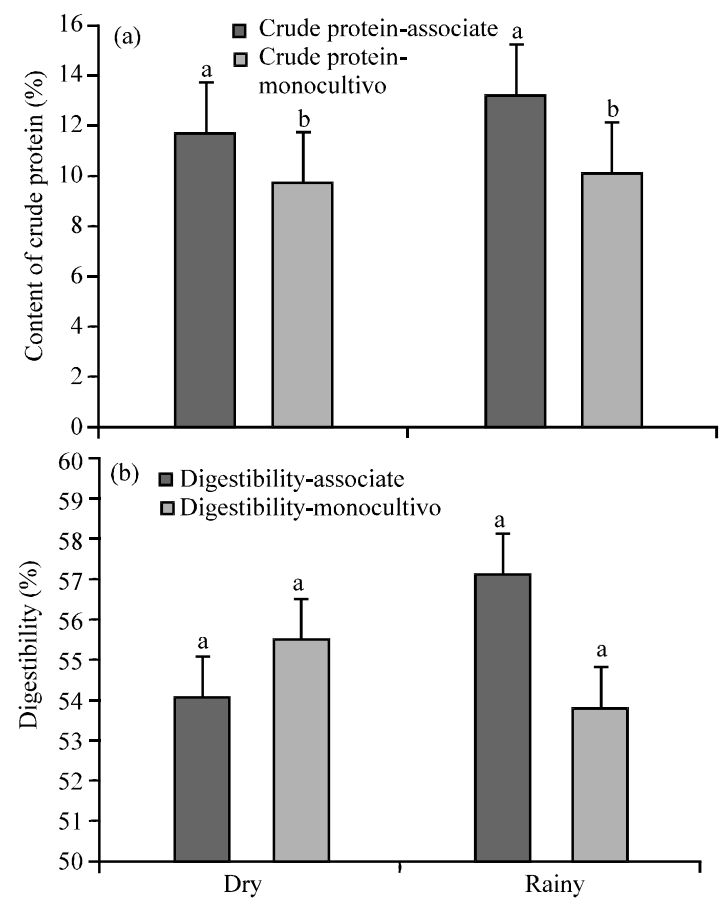

Fig. 4: Content of crude protein and digestibility and in Brachiaria pasture in monoculture and in association

the annualn management costs of the monoculture system were calculated to be US\$ 321.64 of which $48 \%$ correspond to labor costs and $52 \%$ to inputs (Table 4).

According to the results of the financial analysis, using production budgets in a 12 years model, it can be said that Silvopastoral systems of Brachiaria associated with Leucaena in pasture are a viable option when compared to conventional systems of Brachiaria monoculture plus chicken manure both in terms of animal productivity and economic performance. The Silvopastoral system showed a positive Net Current Value (NCV) of US\$ 479.18 and an Internal Return Rate (IRR) of $33 \%$ (Table 5). This coincides with what has been reported by Turcios (2008) who found that the use of a Leucaena forage bank increase milk production to the extent of a greater utility of 25,30 and $90 \%$, provided by the diminished need for supplements.

Moreover, Cino et al. (2006) and Lamela et al. (2010) report that the use of Leucaena forage banks has a profitability $50 \%$ greater than Conventional pasture systems and Sanchez (2007) and Sanchez et al. (2008) indicates that the use of these forage trees is a viable alternative to externally purchased supplements. It is truly important to mention that the use of Silvopastoral systems not only has benefits upon animal productivity and ultimately for the economy of the producer but also
Table 4: Costs of establishment in labor and inputs and management costs for a silvopastoral system and a conventional system per hectare

\begin{tabular}{lcc}
\hline Indicators & $\begin{array}{c}\text { Brachiaria+ } \\
\text { Leucaena }\end{array}$ & $\begin{array}{c}\text { Brachiaria+ } \\
\text { chicken manure }\end{array}$ \\
\hline Brachiaria establishment (wages) & $139.00^{*}$ & 139.00 \\
Leucaena establishment (wages) & 92.70 & 0.00 \\
Brachiaria inputs & $886.80^{* *}$ & 886.80 \\
Leucaena inputs & 65.25 & 0.00 \\
Calves manage (wages) & 46.33 & 115.83 \\
Suplementation & 0.00 & 76.65 \\
Veterinary inputs & 50.19 & 50.19 \\
\hline${ }^{*}$ It appraises of change US\$ 1 $=500$ colones. & ${ }^{* *}$ Fashion costs closely \\
outlying, it fences electric & &
\end{tabular}

Table 5: Costs and income for a 12 years model for a B. brizontha+ Leucaena system and a $B$. brizontha+chicken manure system

\begin{tabular}{lrc}
\hline Indicators & $\begin{array}{r}\text { Brachiaria } \\
\text { Leucaena }\end{array}$ & $\begin{array}{r}\text { Brachiaria+ } \\
\text { chicken manure }\end{array}$ \\
\hline Establishment cost & $952.07^{*}$ & 886.80 \\
Manpower for establishment & 231.60 & 139.00 \\
Manpower maintenance & 131.27 & 154.42 \\
Veterinary inputs & 50.19 & 50.19 \\
Suplementation inputs & 0.00 & 117.63 \\
Revenues for calves sale in foot & 368.45 & 256.64 \\
\hline
\end{tabular}

${ }^{*}$ US $\$ 1=500$ colones

that there exist a series of positive externalities that can be obtained with the use of these systems such as; wood production, nitrogen fixation, carbon sequestration, farm diversification, formation of corridors between forests, soil quality improvements and improvements to the balance of greenhouse gases, leading to a greater diversity of farm products (Alonzo et al., 2001; Casasola et al., 2001; Sanchez and Crespo, 2004; Betancourt et al., 2007; Rodriguez et al., 2008).

\section{CONCLUSION}

Based on the findings of this study, it can say that the use of silvopastoral systems that combine Brachiaria with Leucaena in pastures is a viable alternative to Conventional systems of monoculture Brachiaria and chicken manure supplements. The use of a Leucaena forage bank is a way to minimize and even replace the use of external inputs (such as chicken manure and/or concentrates) as dietary supplements since, the benefits of this forage tree can be felt not only animal productivity but also in the sustainability of the whole system of the environment and as a final product in the economic improvement of the producer.

Since there were no significant differences found between the availability of Brachiaria in association with Leucaena and monoculture Brachiaria and the quality was improved in the Silvopastoral system, there can conclude that establishing Leucaena in association with grasses is an alternative for improving the quality and availability of the grass plants, increase the system sustainability and reduce the use of external inputs. For its high quality and 
availability in the dry season, it can be said that the use of Leucaena foliage is an alternative for counteracting the problem of low animal productivity in the dry season due to the low quality and availability of pasture grasses.

The use of forage trees in animal alimentation could be a viable alternative for obtaining environmentallyfriendly animal production since as is known, one of the limiting elements for this certification is the use of organic sources of alimentation. However, it definitely represents a technological innovation for the tropical livestock.

\section{REFERENCES}

Abarca, S., 1997. Environment and forest-friendly livestock: A sustainable alternative. Agronomia Costarricense, 21: 285-297.

Alonzo, Y.M., M. Ibrahim, M. Gomez and K. Prins, 2001. Potentials and limits for the adoption of silvopastoral systems for milk production in Cayo, Belice. Agroforesteria en las Americas, 8: 24-27.

Andrade, J.H., M. Ibrahim, F. Jimenez, B. Finegan and D. Kass, 2000. Productive dynamics of silvopastoral systems with Acacia mangium and Eucalyptus deglupta in the humid tropics. Agroforesteria en las Americas, 7: 50-52.

Betancourt, H., D. Pezo, J. Cruz and J. Beer, 2007. Bio-economic impacts of pasture degradation in dual purpose farms in El Chal, Peten, Guatemala. Pastos y Forrajes, 30: 169-175.

Caceres, O. and E. Gonzalez, 1998. Nutritional value of tropical tree and shrub forages. IV. Leucaena leucocephala cv. Cunningham. Pastos y Forrajes, 21: 265-270.

Camero, A.R., 1996. The development of silvopastoral systems and their perspectives in meat and dairy production in the tropics. Proceedings of the International Seminary on Silvopastoral Systems: Alternatives for a Modern and Competitive LivestockRaising, (SSAMCLR'96), CATIE, Turrialba, Costa Rica, pp: 15-30.

Casasola, F., M. Ibrahim, C. Harvey and C. Kleinn, 2001. Characterization and productivity of traditional silvopastoral systems in Moropotente, Esteli, Nicaragua. Agroforesteria en las Americas, 8: 17-20.

Castillo, E., T.E. Ruiz, A. Elias, G. Febles, J. Galindo, B. Chongo and J.L. Hernandez, 2002. Effect of the inclusion of a protein and energy supplement in the behavior of male bovines that consume Leucaena associated with star grass. Cuban J. Agric. Sci., 36: $51-55$

Cino, M.D., E. Castillo and J. Hernandez, 2006. Beef cattle alternatives in silvopastoral systems with Leucaena leucocephala: Economic and financial indicators. Cuban J. Agric. Sci., 40: 25-29.
Cuadrado, C.H., L. Torregroza and M.N. Jimenez, 2004. Comparison of four Brachiaria grass species in pasture with beef cattle. MVZ-Cordoba, 9: 438-443.

Delgado, D.C. and J. Cairo, 2008. Degradability of Gliricidia sepium and Leucaena leucocephala in water buffalo and beef cattle. Cuban J. Agric. Sci., 42: 375-379.

Galindo, J., R. Pedraza and D. Garcia, 2005. Impacts of trees, bushes and legumes in the ecology of animals that consume fibrous diets. Pastos y Forrajes, 28: $59-59$.

Garcia, D.E., H.B. Wencomo, M.G. Medina, Y. Noda, L.J. Cova and I. Spengler, 2008a. Evaluation of the nutritional quality of seven ecotypes of Leucaena macrophyla (Benth) in a red clay soil. Revista Facultad Agronomia, 25: 43-67.

Garcia, D.E., H.B. Wencomo, M.E. Gonzalez, M.G. Medina, L.J. Cova and I. Spengler, 2008b. Evaluation of seventeen accessions of Leucaena leucocephala based on the nutritional quality of forage. Zootecnia Trop., 26: 9-18.

Garcia, D.E., H.B. Wencomo, M.G. Medina, L.J. Cova and M.E. Gonzalez et al., 2008c. Inter-specific variation of the nutritional quality of seventeen accessions of Leucaena. Avances en Investigacion Agropecuaria, 12: $67-80$.

Gutierrez, M.A.O., 1996. Pasture and Forage Plants in Guatemala: Their Management and Use, the Basis of Animal Production. E y G Publications, Guatemala, pp: 318 .

Hernandez, I., E.J. Benavides, E. Perez and L. Simon, 2000. Effect of combined prunings on biomass production of Leucaena leucocephala during the dry season in Cuba. Pastos y Forrajes, 23: 39-45.

Holguin, V.A. and M. Ibrahim, 2005. Forage banks of firewood trees. Field Notebook Series, INPASA, Turrialba, Costa Rica, pp: 23.

Lamela, L., E. Castillo, J. Iglesias and A. Perez, 2005. Main advances in the introduction of silvopastoral systems in Cuban production conditions. Pastos y Forrajes, 28: $47-57$

Lamela, L., R.B. Soto, T. Sanchez, F. Ojeda and I. Montejo, 2010. Milk production in an association of Leucaena leucocephala, Morus alba and Pennisetum purpureum CT-115 with irrigation. Pastos y Forrajes, 33: 1-14.

Lobo Di Palma, M.V., 2006. Leguminous foraging shrubs in bovine production systems. National Institute of Agricultural Innovation and Technological Transfers, Costa Rica Soil Science Association, Costa Rica, pp: 9. 
Lopez, O., L. Simon, L. Lamela and T. Sanchez, 2010. Productive evaluation of developing females in milkproducing genotypes in an association of grasses with Leucaena. Pastos y Forrajes, 33: 30-42.

Obispo, N.E., P. Pares, C. Hidalgo, J. Palma and S. Godoy, 2001. Consumption of forage and daily weight gain in beef cattle supplemented with protein sources. Zootecnia Trop., 19: 423-442.

Palma, J.M., M. Aguirre, C. Cardenas, A. Moya, 1999. Nutritional value of three leguminous trees in the dry tropics of Mexico. Pastos y Forrajes, 22: 57-63.

Rodriguez, I., G. Crespo, V. Torres, B. Calero and A. Morales et al., 2008. Integral evaluation of the soilplant complex in a dairy production unit with tree-pasturing in the province of La Habana, Cuba. Cuban J. Agric. Sci., 42: 403-410.

Sanchez, A., C. Romero and R. Flores, 2005. Production of dry material of Leucaena leucocephala at different ages and in different seasons with an artisanal irrigation system. Zootecnia Trop., 23: 39-47.

Sanchez, S. and G. Crespo, 2004. Behavior of soil macrofauna in pastures with grass alone or intercropped with Leucaena. Pastos y Forrajes, 27: 347-353.
Sanchez, S.L.Y., 2007. Characterization of labor in cattle farms and profitability of forage banks in Esparza, Costa Rica. Master's Thesis, CATIE, Turrialba, Costa Rica.

Sanchez, T., L. Lamela, O. Lopez and M. Benitez, 2008. Productive behavior of Cuban Mambi milk cows in association grasses and Leucaena leucocephala $\mathrm{cv}$. Cunninngham. Pastos y Forrajes, 31: 45-53.

Simon, L., K. Hernandes and O. Lopez, 2009. Productive behavior of male Holstein $\mathrm{x}$ Cebu in silvopastoral systems. Tech. Note Pastos y Forrajes, 32: 36-42.

Torres, A.R., E. Chacon, S. Armas and F. Espinoza, 2005. Effect of planting patterns on the production of raw protein in protein banks of Leucaena leucocephala (Lam). Zootecnia Trop., 23: 27-38.

Turcios, H.S., 2008. Evaluation of decision-making processes for the adoption of protein banks with Leucaena (Leucaena leucocephala) and its effect as a nutritional supplement for milk cows in dual purpose systems in el Chal, Petan, Guatemala. Master's Thesis, CATIE, Turrialba, Costa Rica. 